\title{
Effect of restoration technique on stress distribution in extensively destroyed premolars: a finite element analysis study
}

\author{
Efeito da técnica restauradora na distribuição de tensões em pré-molares extensamente destruídos: uma análise \\ por elementos finitos
}

\author{
Wagner Araújo de NEGREIROS` \\ Rômulo Rocha REGIS ${ }^{1}$ \\ Karina Matthes de Freitas PONTES' \\ Antônio Materson da SILVA' \\ Francisco Ilson da SILVA JUNIOR²
}

\section{ABSTRACT}

\section{Objective}

The objective of this study by the finite element method was to analyze the stress distribution on a single-rooted mandibular premolar tooth restored in two different ways.

\section{Methods}

Laboratory simulation considered the following situations: 1) premolar restored with gold cast post and ceramic crown; 2) premolar restored with glass fiber post, composite resin core and ceramic crown. For this we used a two-dimensional model of a premolar with load application of $300 \mathrm{~N}$ in the axial and oblique directions within the ANSYS program for Windows.

\section{Results}

Under the axial load, a higher concentration of stresses was observed around the cast post (166 MPa). In the oblique load simulation, there was a concentration of stresses on the buccal root wall, internally and externally, in the tooth restored with cast post (222 MPa). In both load directions, the glass fiber post dissipated the stress received with greater uniformity (55 to $111 \mathrm{MPa}$ ).

\section{Conclusion}

These data suggested that from the biomechanical point of view, the use of a glass fiber post and composite resin core could be more advantageous than the cast post technique for a mandibular single-rooted premolar tooth.

Indexing terms: Dental prosthesis. Dental restoration failure. Laboratory research. Post and core technique.

\section{RESUMO}

\section{Objetivo}

Analisar, por meio do método dos elementos finitos, a distribuição de tensões em elemento dental pré-molar inferior unirradicular restaurado de duas maneiras distintas.

\section{Métodos}

A simulação laboratorial considerou as seguintes situações: 1) pré-molar restaurado com núcleo metálico fundido em liga áurea e coroa em cerâmica; 2) pré-molar restaurado com pino de fibra de vidro, núcleo de preenchimento em resina composta e coroa em cerâmica. Para isso foi utilizado um modelo bidimensional de um pré-molar com aplicação de carga de $300 \mathrm{~N}$ nas direções axial e oblíqua com uso de programa ANSYS para Windows.

\section{Resultados}

Diante da carga axial, foi observada uma maior concentração de tensões na região do núcleo fundido (166 Mpa). Na simulação de carga oblíqua, observou-se uma concentração de tensões na parede radicular vestibular, interna e externamente, no dente restaurado com núcleo fundido (222 Mpa). Nas duas situações em estudo, o pino de fibra de vidro e núcleo de preenchimento dissipou, com maior uniformidade, a tensão recebida (55 a $111 \mathrm{Mpa}$ ).

\section{Conclusão}

Esses dados sugerem que o uso de pino de fibra pré-fabricado e núcleo de preenchimento em resina composta pode ser mais vantajoso que a indicação de núcleo fundido, sob o ponto-de-vista biomecânico, em dente pré-molar inferior unirradicular.

Termos de indexação: Prótese dentária. Falha de restauração dentária. Investigação laboratorial. Técnica para retentor intrarradicular.

\footnotetext{
${ }^{1}$ Universidade Federal do Ceará, Faculdade de Farmácia, Odontologia e Enfermagem, Departamento de Odontologia Restauradora. Rua Alexandre Baraúna, 949, Rodolfo Teófilo, 60430-160, Fortaleza, CE, Brasil. Correspondência para / Correspondence to: WA NEGREIROS. E-mail: <wagnerufc@ yahoo.com.br>.

${ }^{2}$ Universidade Federal do Ceará, Departamento de Engenharia Mecânica e de Produção, Centro de Tecnologia. Fortaleza, CE, Brasil.
} 


\section{INTRODUCTION}

In the scientific literature there are still controversies about the increase in susceptibility to fracture of teeth, and the use of intracanal retainers to increase the strength of debilitated roots after endodontic therapy ${ }^{1-4}$. Clinically, it has been verified that when teeth without intraradicular retainers have been restored with total crowns, their longevity was shown to be greater that of teeth restored with these retainers. However, in the restoration of extensively debilitated teeth, it is certain that they commonly require the use of an intracanal system with the main purpose of providing the prosthetic part with retention and stability. Generically, the use of intraradicular retainers may be classified into two categories: Cast cores and prefabricated posts ${ }^{5-6}$. In certain clinical situations, the selection of the type of retainer depends on various factors, among them: The degree of tooth destruction; localization of the tooth in the arch; root morphology; periodontal conditions; extension of the dental prosthesis and occlusal stress ${ }^{7}$.

Various scientific studies have endeavored to observe the biomechanical behavior of anterior teeth after restoration with intraradicular retainers and submitted to oriented loads ${ }^{8-10}$. The use of cast metal retainers has been associated with the more frequent occurrence of irreparable failures as opposed to the indication of prefabricated glass fiber and carbon posts ${ }^{11}$. Nevertheless, very little is known about the biomechanical behavior of posterior teeth restored with intraradicular retainers ${ }^{12-13}$. In the present study, the authors sought to evaluate the stress distribution on extensively destroyed premolars that were restored with a metal core cast with gold alloy, or with a glass fiber post and resin composite filling core. Understanding of the stresses induced on the retainer, dental tissue and surrounding bone tissue may determine the success of the restorative therapy, and these aspects may be elucidated by the finite element methodology $y^{14-15}$.

\section{METHODS}

For this study, the finite element method was used in a two dimensional analysis (axes of the $X$ and $Y$ coordinates), from a geometric drawing of a uniradicular mandibular premolar, with anatomic dimensions similar to those of the human tooth ${ }^{16}$, performed by means of the Rhinoceros ${ }^{\circledR} 3.0$ software (NURBS Modeling for Windows, USA). In this drawing the biologic dental structures and surrounding tissues were delimited in different colors: enamel, dentin, periodontal ligament, cortical bone and spongy bone. The cement was not differentiated because it presents properties similar to those of dentin. The main materials used in the restoration were also defined: gutta percha, glass fiber post, resin composite, core cast in gold, and ceramic. The agent for cementing the intracanal retainer could be considered the same in both restorative situations, and was therefore not discriminated in this study.

In the ANSYS for Windows software (SIMULIA, Providence, RI, USA) a vectorized image (mesh) was created from the original drawing, enabling it to be used for the finite element analysis by means of mathematical calculations. Thus, two dental models were generated for the biomechanical study: Model 1 - mandibular premolar restored with core cast in gold and ceramic crown; Model 2 - mandibular premolar restored with glass fiber post, resin composite filling core and ceramic crown. The force applied was $300 \mathrm{~N}$ according to Ou et al. ${ }^{17}$, in the axial (long axis of the tooth in the central groove) and oblique (at $45^{\circ}$ to the internal slope of the vestibular cusp) directions. The two models studied were considered isotropic, elastic and continuous. For effect of the mathematical tests, the modulus of elasticity (GPa) and Poisson coefficient of the biologic structures and restorative materials contained in Table 1 were used. Qualitative and quantitative analyses were performed by means of visual observation of the graphic images of the Von Mises stresses and their color gradients, generated and printed by the ANSYS software.

Table 1. Modulus of elasticity (GPa) and poisson coefficient.

\begin{tabular}{ccc}
\hline Material & $\begin{array}{c}\text { Modulus of Elasticity } \\
(\mathbf{G P a})\end{array}$ & Poisson Coefficient \\
\hline Dentin & 18.6 & 0.31 \\
Enamel & 41 & 0.30 \\
Gutta percha & 0.00069 & 0.45 \\
Periodontal & 0.0689 & 0.45 \\
Ligament & 13.7 & 0.30 \\
Cortical Bone & 1.37 & 0.30 \\
Spongy Bone & 69 & 0.28 \\
Porcelain & 22.2 & 0.30 \\
Resin composite & 33 & 0.33 \\
Glass Fiber Post & 78 & 0.44 \\
Gold & &
\end{tabular}

\section{RESULTS}

When the force of 300N was applied in the axial direction, a greater accumulation of Von Mises stresses was 
observed in the region of the cast metal core (166 MPa) (figure 1), in contrast with a greater dissipation of stresses on the dental tissues surrounding the glass fiber post ( 55 $\mathrm{MPa}$ ) (figure 2). When the same force was applied at a slope of $45^{\circ}$, peaks of stresses were observed on the vestibular root wall, both internally and externally, on the tooth restored with the cast metal core (222 MPa) (figure 3$)$ in contrast with the glass fiber post condition that presented a more uniform stress distribution on the post itself and surrounding dentin tissue (111 MPa) (figure 4).

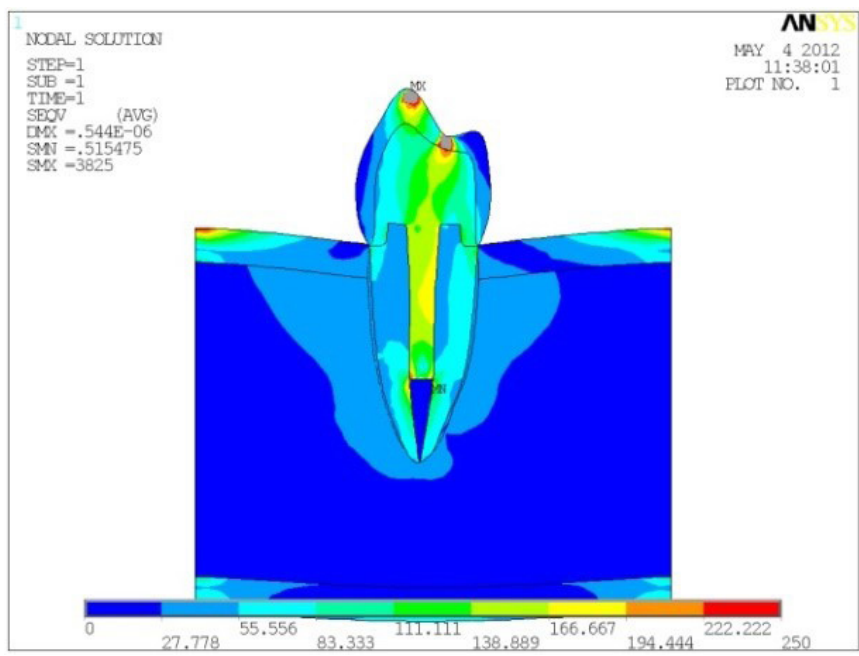

Figure 1. Stress distribution on premolar restored with cast metal core, after axial load.

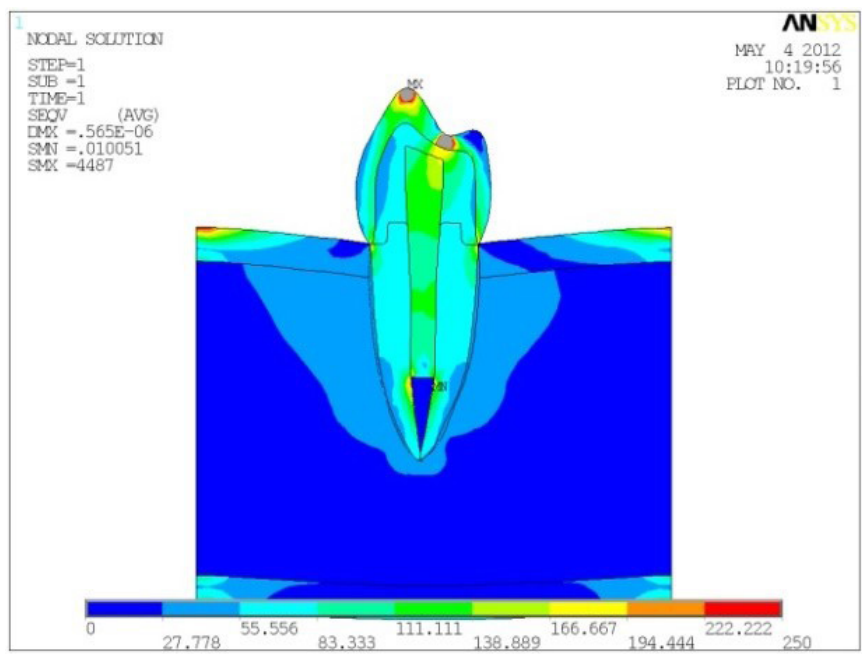

Figure 2. Stress distribution on premolar restored with glass fiber post and resin composite filling core, after axial load.

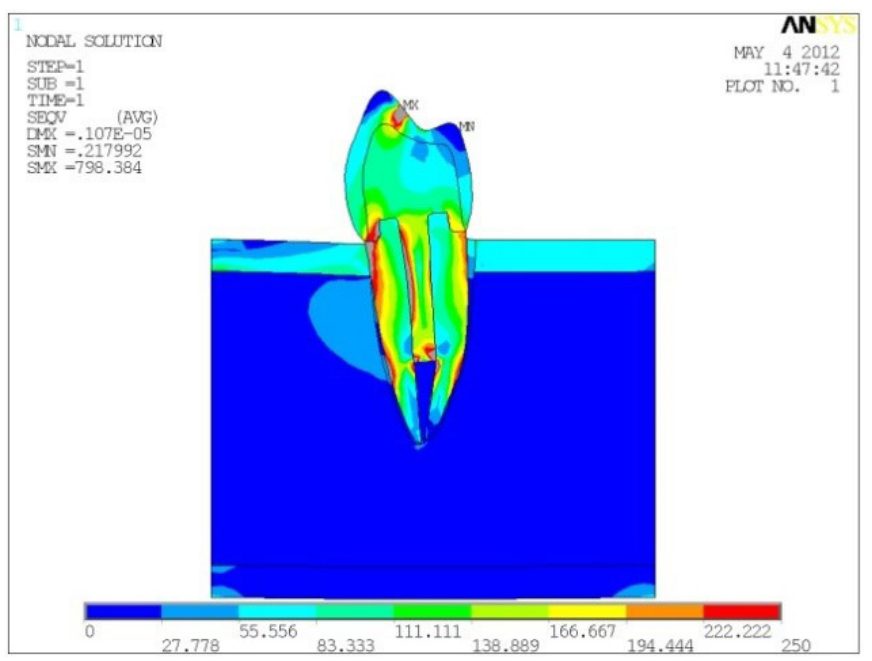

Figure 3. Stress distribution on premolar restored with cast metal core, after oblique load.

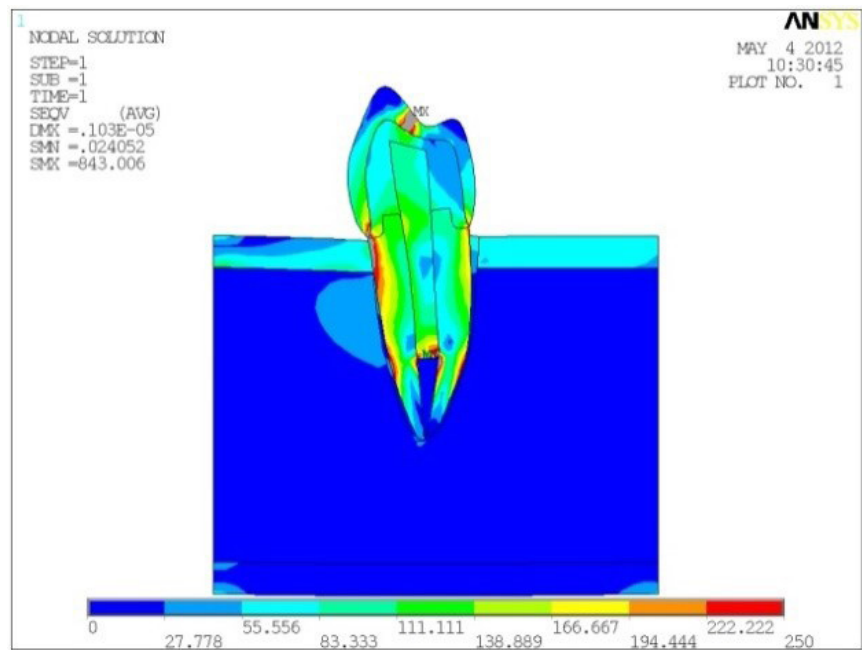

Figure 4. Stress distribution on premolar restored with glass fiber post and resin composite filling core, after oblique load.

\section{DISCUSSION}

The use of cast metal cores has been documented for over 50 years. The easily obtained technique; precise fit to root walls; possibility of selecting alloys, and clinical longevity have made this the standard procedure (control group) in intractable retention in the majority of experimental trials. Nevertheless, commercial prefabricated retainers, with additional properties and interest to clinicians have appeared: Maintenance of the aseptic chain after endodontic therapy; esthetics; need for less conservative preparation, flexibility similar to that of dentin, and compatibility with adhesive cements ${ }^{18-19}$. 
In the present study, the authors verified that in the simulation of vertical load, the cast metal core (Figure 1) accumulated higher internal stresses than those of the glass fiber post (Figure 2), which were uniformly dissipated throughout the root; This phenomenon may be understood as a benefit of metal cores in the face of loads of low magnitude; however, it is possible for peaks of stresses to occur at points located in the root (non uniform stresses) that generate "catastrophic" fracture in the face of excessive occlusal stress ${ }^{20-21}$. This aspect of alloys with higher modulus of elasticity, may be potentiated, if alloys such as Cobalt-chrome $(\mathrm{CoCr})$ or Nickel-chrome $(\mathrm{NiCr})$ were used ${ }^{10,22}$.

Considering the simulation of oblique load, the authors verified a concentration of stresses on the vestibular root wall, both internally and externally, on the tooth restored with the cast core (Figure 3), with higher potential for the occurrence of root fracture than in the condition with the use of the glass fiber post (Figure 4).In the latter situation, the compatibility existent between the modulus of elasticity of the glass fiber post and dentin tissue allowed greater dissipation of forces throughout the entire root, reducing the peaks of stresses in localized areas ${ }^{18,23}$.

Investigations into the opinions of clinical dental surgeons regarding the indication of retainers have shown preference for the use of cast cores rather than prefabricated posts $^{2-3}$. To the contrary, a recent trend has been perceived in the use of materials with biomechanical properties similar to those of the dental structures, particularly those supported by a body of scientific laboratory evidence ${ }^{23}$. Nevertheless, the clinical performance of these two types of retainers was similar after 3 years of follow-up ${ }^{24}$, with comparable success rates in systematic reviews ${ }^{4,22}$. In addition to selecting the correct retainer, clinical procedures

\section{REFERENCES}

1. Skupien JA, Sarkis-Onofre R, Cenci MS, Moraes RR, PereiraCenci T. A systematic review of factors associated with the retention of glass fiber posts. Braz Oral Res. 2015;29(1):1-8.

2. Eckerbom M, Magnusson T. Restoring endodontically treated teeth: a survey of current opinions among board-certified prosthodontists and general dental practitioners in Sweden. Int J Prosthodont. 2001;14(3):245-9.

3. Upadhyaya V, Bhargava A, Parkash H, Chittaranjan B, Kumar V. A finite element study of teeth restored with post and core: Effect of design, material, and ferrule. Dent Res J. 2016;13(3):233-8. doi: 10.4103/1735-3327.182182 must always be adopted to reduce the stress arising from occlusal loading, such as the correct occlusal adjustment and reduction in cusp height of posterior teeth ${ }^{25}$.

Two dimensional analysis by means of the finite element method is the best indicated for extremely thin or extensively thick bodies from the mechanical engineering point of view. In effect, the study of stresses induced on a tooth may be best elucidated in the three dimensions of space (also considering the $\mathbf{Z}$ axis), and this was one of the limitations of this study. However, under the conditions proposed, it was possible to discuss the restoration of a mandibular uniradicular premolar and its biomechanical implications.

\section{CONCLUSIONS}

Considering the limitations of this laboratory study, the authors were able to observe greater uniformity in the distribution of stresses on a premolar tooth restored with a glass fiber post and resin composite filling core, in comparison with the other, restores with a cast core. This datum suggested that the use of intracanal retainers with a module of elasticity closest to that of dentin could be more advantageous, from the biomechanical point of view, in mandibular uniradicular premolar teeth.

\section{Collaborators}

WA NEGREIROS was responsible for the execution of the biomechanical testing, review of the scientific literature and redaction of the article. RR REGIS, KMF PONTES e AM SILVA participated in the review and article writing. FI Silva Junior assisted in the area of mechanical engineering to the biomechanical test execution and participated in the writing of the article.

4. Ploumaki A, Bilkhair A, Tuna T, Stampf S, Strub JR. Success rates of prosthetic restorations on endodontically treated teeth; a systematic review after 6 years. J Oral Rehabil. 2013;40(8):61830. doi: 10.1111/joor.12058

5. Yang A, Lamichhane $A, X u C$. Remaining coronal dentin and risk of fiber-reinforced composite post-core restoration failure: a meta-analysis. Int J Prosthodont. 2015;28(3): 258-64. doi: 10.11607/ijp.4157

6. Boyarsky H, Davis R. Root fracture with dentin-retained posts Am J Dent. 1992;5(1):11-4.

7. Vârlan C, Dimitriu B, Vârlan V, Bodnar D, Suciu I. Current opinions concerning the restoration of endodontically treated teeth: basic principles. J Med Life. 2009;2(2):165-72. 
8. de Castro Albuquerque R, Polleto LT, Fontana RH, Cimini CA. Stress analysis of na upper central incisor restored with different posts. J Oral Rehabil. 2003; 30: 936-43. doi: 10.1046/j.13652842.2003.01154.x

9. Asmussen E, Peutzfeldt A, Sahafi A. Finite element analysis of stresses in endodontically treated, dowel-restored teeth. J Prosthet Dent. 2005;94(4):321-9. doi: 10.1016/j. prosdent.2005.07.003

10. Belli S, Eraslan Ö, Eraslan O, Eskita囚cıO邓lu G. Effect of restoration technique on stress distribution in roots with flared canals: an FEA study. J Adhes Dent. 2014;16(2): 185-91. doi: 10.3290/j. jad.a30686

11. Lewis $R$, Smith BG. A clinical survey of failed post retained crowns. Br Dent J. 1988;165(3):95-7.

12. Magne P, Goldberg J, Edelhoff D, Güth JF. Composite resin core buildups with and without post for the restoration of endodontically treated molars without ferrule. Oper Dent. 2016;41(1):64-75. doi: 10.2341/14-258-L

13. Dua N, Kumar B, Arunagiri D, Iqbal M, Pushpa S, Hussain J. Comparative evaluation of the effect of different crown ferrule designs on the fracture resistance of endodontically treated mandibular premolars restored with fiber posts, composite cores, and crowns: An ex-vivo study. J Conserv Dent. 2016;19(3): 264-9. doi: 10.4103/0972-0707.181945

14. Ulbrich NL, Franco APGO, Zielak JC, Mathias AL. The stress evaluation of root post using the finite element analysis. RSBO. 2011 8(2):189-93.

15. Fu G, Deng F, Wang L, Ren A. The Three-dimension finite element analysis of stress in posterior tooth residual root restored with postcore crown. Dent Traumatol. 2010;26(1):6469. doi: 10.1111/j.1600-9657.2009.00829.x

16. Madeira MC. Anatomia da face. $8^{a}$ ed. São Paulo: Sarvier; 2013.

17. Ou KL, Chang CC, Chang WJ, Lin CT, Chang KJ, Huang HM. Effect of damping properties on fracture resistance of root filled premolar teeth: a dynamic finite element analysis. Int Endo J. 2009;42(8):694-704. doi: 10.1111/j.1365-2591.2009.01570.x
18. Ratnakar P, Bhosgi R, Metta KK, Aggarwal K, Vinuta S, Singh N Survey on restoration of endodontically treated anterior teeth: a questionnaire based study. J Int Oral Health. 2014;6(6):41-5.

19. Pereira JR, do Valle AL, Shiratori FK, Ghizoni JS, Bonfante EA. The effect of post material on the characteristic strength of fatigued endodontically treated teeth. J Prosthet Dent. 2014;112(5):1225-30. doi: 10.1016/j.prosdent.2014.03.014

20. Hu YH, Pang LC, Hsu CC, LauYH. Fracture resistance of endodontically treated anterior teeth restored with four postand-core systems. Quintessence Int. 2003;34(5):349-53.

21. Galhano GA, Valandro LF, de Melo RM, Acotti R, Bottino MA. Evaluation of the flexural strenght of carbon fiber-, quartz fiber-, and glass fiber-based posts. J Endod. 2005;31(3):209-11 .

22. Figueiredo FE, Martins-Filho PR, Faria-E-Silva AL. Do metal postretained restorations result in more root fractures than fiber postretained restorations? A systematic review and meta-analysis. J Endod. 2015;41(3):309-16. doi: 10.1016/j.joen.2014.10.006

23. Novais $V R$, Rodrigues $R B$, Simamoto Júnior $P C$, Lourenço $C S$, Soares $C$. Correlation between the Mechanical Properties and Structural Characteristics of Different Fiber Posts Systems. Braz Dent J. 2016;27(1):46-51. doi: 10.1590/0103-6440201600377

24. Sarkis-Onofre R, Jacinto Rde C, Boscato N, Cenci MS, PereiraCenci T. Cast metal vs. glass fibre posts: a randomized controlled trial with up to 3 years of follow up. J Dent. 2014;42(5):582-7. doi: 10.1016/j.jdent.2014.02.003

25. Liu S, Liu Y, Xu J, Rong Q, Pan S. Influence of occlusal contact and cusp inclination on the biomechanical character of a maxillary premolar: a finite element analysis. J Prosthet Dent. 2014;112(5):1238-45. doi: 10.1016/j.prosdent.2014.04.011
Received on: 11/5/2016

Final version resubmitted on: 28/11/2016

Approved on: 7/12/2016 